\title{
EFFECT OF AQUEOUS EXTRACT OF COCHLOSPERMUM PLANCHONII RHIZOME ON SOME KIDNEY AND LIVER FUNCTIONAL INDICIES OF ALBINO RATS
}

\author{
*Nafiu, M.O., Akanji, M. A., and Yakubu, M. T. \\ Department of Biochemistry, University of Ilorin, Ilorin, Nigeria. \\ Email: olumikail@gmail.com
}

\begin{abstract}
Aqueous extract of Cochlospermum planchonii Hook. Ef. x Planch rhizome was investigated for its toxic effects in albino rats using some liver and kidney functional indices as 'markers'. Thirty six albino rats weighing $200.08 \pm 10.21$ were randomly assinged into six groups (A-F) of six animals each. Animals in groups A-E were orally administered on daily basis with $1 \mathrm{ml}$ of the extract corresponding to $50 \mathrm{mg} / \mathrm{kg}$ body weight of the extract for $1,3,5,10$ and 15 days while those in the control group received orally $1 \mathrm{ml}$ of distilled water. Rats in all the groups were sacrificed 24 hours after the completion of their respective doses. The extract significantly $(\mathrm{P}<0.05)$ decreased alkaline phosphatase (ALP) activities in the liver leading to $80.95 \%$ loss by the end of the experimental period. While there was no consistent pattern in the kidney ALP activity and serum bilirubin level, the serum enzyme compared well $(\mathrm{P}>0.05)$ with the control value. There was no effect $(\mathrm{P}>0.05)$ on the acid phosphatase activity of the tissues and serum of the animals. The extract also reduced the urea, albumin and creatinine content in the serum of the animals. The alterations in the biochemical parameters by the aqueous extract of Cochlospermum planchoni may have consequential effects on the normal functioning of the liver and kidney of the animals. Therefore, the $50 \mathrm{mg} / \mathrm{kg} \mathrm{body}$ weight of the aqueous extract of Cochlospermum planchoni rhizome may not be completley safe as an oral remedy.
\end{abstract}

Keywords: Cochlospermum planchonii, Cochlospermaceae, functional indices, liver, kidney

\section{Introduction}

Medicinal herbs are moving from fringe to mainstream use with a greater number of people seeking remedies and health approaches free from side effects occassionally caused by synthetic chemicals. For a variety of reasons, more individuals nowadays prefer to take personal control over their health with the use of herbal medicines, not only to prevent diseases but also to treat them. This is particularly true for a wide variety of illnesses such as common cold, scratches, malaria fever and stomach disorders which are readily treated at home (Kincheloe, 1997). WHO estimated that about three-quarters of the world's population currently use herbs and other forms of traditional medicines to treat their diseases (Farnsworth et al., 1985).

With the upsurge in the use of herbal medicine, thorough scientific investigations of these plants are imperative in order to provide information on their safety and toxicity risk (Palambo, 2006). One such plant that is widely claimed in Traditional Medicine of Nigeria to be used in the management of several ailments such as malaria and enteric fever, diabetes mellitus, infertility, gonorrhea and diarrhoea (Igoli et al., 2002) without recourse to its safety or toxicity risk is Cochlospermum planchonii.

Cochlospermum planchonii (Cochlospermaceae) otherwise known as Gbehutu or Feru (Yoruba- Western Nigeria) is a shrub of about 2-4 m tall, with scarbid trilobed leaves (Blench, 2007). The rhizomes and leaves are separately used locally in the treatment of jaundice, malaria, diabetes and diarrhoea (Anthony et al., 2005; Atawodi, 2005). The decoction of the root bark of the plant is used for treating hepatic fever, hepatobililary affections (black toilet fever) and haemolytic anaemia in Burkina Faso (Aliyu et al., 1995). In Mali, powdered leaves and the concotion of the root as well as those of Entada africans and Erythrina senegalensis are used for the treatment of malaria fever and jaundice. Again, the rhizomes are also used in the treatment of stomach diorders, typhoid fever and urinary tract infections (Togola et al., 2008).

The leaf, stem bark and root bark of $C$. planchonii have been shown to have strong fungitoxicity against Colletotrichum capsici (Nduagu et al., 2008). Again, the leaf oil of $C$. planchonii have been shown to possess a superior anti-plasmodial effect in vitro over chloroquine (Benoit-Vical et al., 1999). Other studies have also suggested trypanocidal properties for the petroleum extract of the stem bark of C. planchonii (Atawodi, 2005) while Anaga and Opara (2009) have revealed that the methanolic root extract of the plant possess CNS depressing activity, analgesic, anti-inflammatory and anti-hyperglycemic activities with minimal toxicity using brine shrimps lethality model.

To the best of our ability, no information exist in the open scientific literature on the toxicity of the aqueous extract of C. planchonii rhizomes in rats. Therefore, the present study was aimed at providing information on the effect of oral administration of aqueous extract of $C$. Planchonii rhizome on some functional indicies of the liver and kidney of Wistar rats. 


\section{Materials and Methods \\ Experimental animals}

A total of thrity six albino rats (Rattus norvegicus) of Wistar strain with average weight of $200.08 \pm 10.21$ were obtained from the Animal Holding Unit of the Department of Biochemistry, University of Ilorin, Ilorin, Nigeria. The animals were housed in aluminum cages under standard conditions (temperature $23 \pm 1 \mathrm{C}$; photoperiod: $12 \mathrm{hr}$ natural light and $12 \mathrm{hr}$ dark; humidity: 45-50\%). They were allowed free access to rat feed (Bendel Feeds and Flour Mills, Ewu, Nigeria) and contaminant free tap water. The animals were acclimatization for two weeks before the commencement of the experiment.

\section{Plant material and authentication}

The plant samples obtained from the traditional herb seller at Oja-oba Market, Ilorin, Nigeria were identifed at the Forest Research Institute of Nigeria (FRIN), Ibadan, Nigeria. A voucher specimen (F.H.I 99093) was deposited at the herbarium of the institute.

\section{Assay kits and other reagents}

The assay kits for alkaline phosphatase (ALP), acid phosphatase (ACP), urea, creatinine and albumin were products of Randox Laboratory Ltd., County Atrim, U.K. All other reagents used were of analytical grade and were obtained from Sigma Aldrich, St. Louis, USA.

\section{Preparation of the extract}

The rhizomes were cut into thin pieces, washed in distilled water, air-dried at room temprature for five days and thereafter milled into powder. A portion $(800 \mathrm{~g})$ of the powder was extracted in 1.6 litres of distilled water followed by thorough shaking for $24 \mathrm{hr}$ with magnetic stirrer. The mixture was then filtered and freeze-dried (Ilshin Freeze-Dryer, Model no: FD5518, Ilshan Laboratory Company Ltd., Seoul, Korea) to give $22.75 \mathrm{~g}$ (percentage yield of 2.84). A calculated amount of the reisude was weighed and reconstituted in distilled water to give the required dose of $50 \mathrm{mg} / \mathrm{kg}$ body weight. The dose used in this study was arrived at from ethnobotanical survey carried out on the plant by the authors.

\section{Animal grouping and administration of extract}

The animals were randomly assinged into six groups (A-F) of six rats each. Rats in the control group were orally administered with $1 \mathrm{ml}$ of distilled water while the animals in the other groups (A-E) were administered orally with same volume corresponding to $50 \mathrm{mg} / \mathrm{kg}$ body weight of the extract for days $1,3,5,10$ and 15 respectively. The animals in each group were sacrificed $24 \mathrm{hrs}$ after the completion of their respective doses. The animals were handled humanely in accordance with the guidelines of European convention for the protection of vertebrate animals and other scientific purposes- ETS-123 (European Treaty Series, 2005).

\section{Preparation of serum and tissue homogenates}

Under ether anaesthesia, the neck was quickly cleared of fur and skin to expose the jugular veins. This animals were thereafter made to bleed through their cut jugular vein. Blood was collected into a clean, dry centrifuge tube and allowed to clot for $30 \mathrm{~min}$ before centrifuging at $33.5 \mathrm{~g} \mathrm{x} 15 \mathrm{~min}$ using Uniscope Laboratory Centrifuge (Model SM800B, Surgifriend Medicals, Essex, England). The sera were thereafter aspirated into clean, dry, sample bottles using Pasteur pipette and were kept frozen overnight before being used for the assays. The animals were thereafter quickly dissected and the liver and kidney removed. The kidney was decapsulated while the liver was clean of blood. The organs were later blotted with a clean tissue paper, weighed and homogenized in $0.25 \mathrm{M}$ sucrose solution (1:5 w/v) as described by Akanji and Yakubu (2000). The homogenates were later transferred into specimen bottles and kept frozen for $24 \mathrm{hrs}$ before analyses.

\section{Determination of biochemical parameters}

The biochemical parameters were determined using standard methods as described for (Wright et al., 1972a), (Wright et al 1972b), Urea (Veniamin and Vakirtzi, 1970), Creatinine (Blass et al., 1974), Albumin (Grant and Kacchman, 1987) and Bilirubin (Evelyn and Malloy, 1938).

\section{Statistical Analysis}

Data were prsented as mean \pm SD of six determinations. Statistical analyses were carried out using one way Analysis of Variance. Differences were considered statistically significant at $\mathrm{P}<0.05$ (Mahajan, 1997). 
Table 1: Effects of aqueous extract of Cochlospermum planchoni rhizome on alkaline phosphatase activities of rat liver and kidney

\begin{tabular}{llcl}
\hline Groups & \multicolumn{3}{c}{ Enzyme activity (U/I) } \\
\hline Control & Liver & Kidney & Serum \\
I & $38.98 \pm 3.50^{\mathrm{a}}$ & $122.71 \pm 12.54^{\mathrm{a}}$ & $10.72 \pm 1.89^{\mathrm{a}}$ \\
II & $16.44 \pm 0.22^{\mathrm{b}}$ & $113.80 \pm 10.52^{\mathrm{b}}$ & $10.72 \pm 1.90^{\mathrm{a}}$ \\
III & $25.64 \pm 2.74^{\mathrm{bc}}$ & $149.92 \pm 8.92^{\mathrm{bc}}$ & $11.00 \pm 2.85^{\mathrm{a}}$ \\
IV & $13.68 \pm 0.59^{\mathrm{bcd}}$ & $143.93 \pm 5.38^{\mathrm{bc}}$ & $10.36 \pm 1.76^{\mathrm{a}}$ \\
V & $15.98 \pm 0.47^{\mathrm{b}}$ & $79.20 \pm 7.59^{\mathrm{bcd}}$ & $10.60 \pm 1.76^{\mathrm{a}}$ \\
\hline
\end{tabular}

Values are mean of 6 replicates \pm SD.

Statistical analysis used was analysis of variance (ANOVA).

${ }_{\mathrm{a}, \mathrm{b}, \mathrm{c}, \mathrm{d}, \mathrm{e}}$ Values carrying superscripts different from the control down the columns are significantly different $(\mathrm{P}<0.05)$.

Table 2: Effects of aqueous extract of Cochlospermum planchoni rhizome on the acid phosphatase activities of rat liver and kidney

\begin{tabular}{llll}
\hline \multicolumn{3}{c}{ Enzyme activity (U/I) } \\
\hline Groups & Liver & Serum \\
\hline Control & $83.75 \pm 0.40^{\mathrm{a}}$ & $143.91 \pm 1.07^{\mathrm{a}}$ & $44.16 \pm 7.06^{\mathrm{a}}$ \\
I & $83.69 \pm 0.33^{\mathrm{a}}$ & $144.38 \pm 0.60^{\mathrm{a}}$ & $43.96 \pm 2.78^{\mathrm{a}}$ \\
II & $84.14 \pm 0.71^{\mathrm{a}}$ & $144.05 \pm 0.06^{\mathrm{a}}$ & $44.09 \pm 5.35^{\mathrm{a}}$ \\
III & $83.28 \pm 0.12^{\mathrm{a}}$ & $144.94 \pm 1.49^{\mathrm{a}}$ & $44.14 \pm 4.53^{\mathrm{a}}$ \\
IV & $83.92 \pm 0.15^{\mathrm{a}}$ & $143.43 \pm 0.80^{\mathrm{a}}$ & $43.72 \pm 1.93^{\mathrm{a}}$ \\
V & $83.34 \pm 0.44^{\mathrm{a}}$ & $144.98 \pm 0.90^{\mathrm{a}}$ & $44.22 \pm 1.36^{\mathrm{a}}$ \\
\hline
\end{tabular}

Values are mean of 6 replicates \pm SD.

Statistical analysis used was analysis of variance (ANOVA).

${ }^{a}$ Values carrying superscripts different from the control down the columns are significantly different $(\mathrm{P}<0.05)$.

Table 3: Effects of aqueous extract of Cochlospermum planchoni rhizome on some liver and kidney functional indicies of albino rat

\begin{tabular}{llccc}
\hline \multicolumn{5}{c}{ Serum concentration $(\mu \mathrm{mol} / \mathrm{l})$} \\
\hline Groups & \multicolumn{2}{c}{ Creatinine } & Albumin & \multicolumn{1}{c}{ Bilirubin } \\
\hline \multirow{2}{*}{ Control } & $4.72 \pm 0.51^{\mathrm{a}}$ & $4.64 \pm 0.37^{\mathrm{a}}$ & $9.67 \pm 0.63^{\mathrm{a}}$ & $4.10 \pm 0.26^{\mathrm{a}}$ \\
I & $1.26 \pm 0.10^{\mathrm{b}}$ & $4.35 \pm 0.01^{\mathrm{a}}$ & $7.49 \pm 0.31^{\mathrm{b}}$ & $1.72 \pm 0.15^{\mathrm{b}}$ \\
II & $1.26 \pm 0.20^{\mathrm{b}}$ & $4.09 \pm 0.64^{\mathrm{b}}$ & $4.56 \pm 0.31^{\mathrm{b}}$ & $1.72 \pm 0.10^{\mathrm{b}}$ \\
III & $3.87 \pm 0.14^{\mathrm{b}}$ & $5.09 \pm 0.20^{\mathrm{b}}$ & $6.60 \pm 0.04^{\mathrm{a}}$ & $18.45 \pm 1.58^{\mathrm{b}}$ \\
IV & $2.90 \pm 0.18^{\mathrm{b}}$ & $3.16 \pm 0.04^{\mathrm{b}}$ & $7.86 \pm 0.62^{\mathrm{b}}$ & $13.41 \pm 1.92^{\mathrm{b}}$ \\
V & $2.74 \pm 0.04^{\mathrm{b}}$ & $1.72 \pm 0.12^{\mathrm{b}}$ & $5.93 \pm 0.01^{\mathrm{b}}$ & $4.18 \pm 0.07^{\mathrm{a}}$ \\
\hline
\end{tabular}

Values are mean of 6 replicates \pm SD.

Statistical analysis used was analysis of variance (ANOVA).

${ }^{\mathrm{a}, \mathrm{b}}$ Values carrying superscripts different from the control down the columns are significantly different $(\mathrm{P}<0.05)$. 


\section{Results}

There was significant $(\mathrm{P}<0.05)$ decrease of alkaline phosphatase activities in the liver of the animals following the administration of the extract. This became manifest immediately after the first dose of the extract (Table 1), by which time, $80.95 \%$ had been lost. On the contrary, there was no consistent pattern in the kidney ALP activity as the values kept fluctuating throughout the exposure period. Furthermore, alkaline phosphatase activity in the serum of extract dosed animals compared well $(\mathrm{P}>0.05)$ with that of the control (Table 1). For acid phosphatase, the extract did not significantly $(\mathrm{P}>0.05)$ alter the enzyme activity in the tissues and serum of the animals throughout the exposure period (Table 2).

Administration of the extract significantly reduced the serum urea, albumin and creatinine content of the animals. While the effect became manifest immediately after the first dose for the urea and albumin, that of creatinine did not manifest until after the third daily doses of the extract (Table 3). In the case of bilirubin, there was an initial decrease until after the first three doses when the serum concentration increased to about three times the control value. By the end of the experimental period, the levels of bilirubin in the serum of the animals compared well with the control (Table 3 ).

\section{Discussion}

Measurement of the activties of 'marker' enzymes in tissues and body fluids can be used in assessing the degree of assault and the toxicity of a chemical compound on organs/tissues (Malomo, 2000; Yakubu et al., 2003). Such measurement can also be used to indicate tissue cellular damage caused by a chemical compound long before it is revealed by histological techniques (Akanji, 1986). Alkaline phosphatase, a 'marker 'enzyme for the plasma membrane and endoplasmic reticulum (Wright and Plummer, 1974; Shahjan et al., 2004), is frequently used to assess the integrity of the plasma membrane (Akanji et al., 1993); such that any alteration in the activity of the enzyme in the tissue and serum would indicate likely damages to the external boundary of the cell (plasma membrane) (Yakubu, 2006). Therefore, the decrease in the liver ALP activities without corresponding increase in the serum enzyme in this study following the administration of aqueous extract of C. Planchonii rhizome could be attributed to either inhibition of the enzyme activity at the cellular/molecular level (Akanji et al., 1993), or inactivation of the enzyme molecules in situ (Umezawa and Hooper,1982 ). This could hamper the normal transportation of required ions or molecules across the membrane (Akanji et al.,1993). It may also affect other metabolic processes where the enzyme is involved; such as synthesis of nuclear proteins, nucleic acids and phospholipids as well as in the cleavage of phosphate esters (Ramalingam and Vimaladevi, 2002). The non consistent pattern of ALP activity displayed by the kidney of the animals may be attributed to an attempt at counteracting the effect of the extract (Nakanishi and Goto, 1975). The lack of an effect on the serum ALP further suggests that the reduction in the liver enzyme was not as a result of membrane labilization, but inactivation or inhibition of the enzyme molecule.

Acid phosphatase is an indicator of damage to the lysosomal membrane (Collins and Lewis, 1971). The absence of an effect by the extract on the ACP activity of the tissues and serum of the animals in this study may be an indication that the lysosomal membrane was not adversely affected. Generally, the aqueous extract of $C$. planchonii rhizome did not alter permeability of the plasma and lysosomal membranes. The pattern of alterations in the phosphatase activity of the tissues indicates that the extract is enzyme and organ selective in excerting its effect.

Albumin, bilirubin, creatinine and urea are among the indices that can be used to evaluate the normal functioning of the liver and kidney of animals (Blass et al., 1974; and Grant and Kacchman, 1987; Saad et al., 2006). Reduction in the levels of serum urea and creatinine is an indication that $C$. planchonii enhanced the clearance functioning of the kidney. Similarly, the reduction in the levels of serum albumin by the extract may be an indication of diminished synthetic function of the liver, resulting probably from hepatocellular damage (Woodman, 1996). This is similar to the findings of Pendota et al. (2010) who reported similar decrease in albumin content of the serum of male rats following the administration of $200 \mathrm{mg} / \mathrm{kg}$ body weight of aqueous extract of Hippobromus pauciflorus leaves to male rats. Bilirubin is an important metabolic product of blood with biological and diagnostic values (Moudgil and Narang, 1989). The non-specific pattern of effect on the bilirubin could possibly suggest physiological response as a result of exposure to the extract which is not part of the normal diet and is most likely not to be toxicologically relevant, more so when no definite pattern was produced (Yakubu et al., 2009).

In conclusion, the extract of Cochlospermum planchonii rhizome has altered the phosphatase activity of the tissues studied as well as the serum albumin, bilirubin, creatinine and urea. These alterations may have consequential effect on the transportations of ions across the cell membrane as well as on the normal functioning of the liver and kidney of the animals. Therefore, the aqueous extract of the rhizome of Cochlospermum planchonii may not be completely safe as oral remedy at the dose of $50 \mathrm{mg} / \mathrm{kg}$ body weight investigated in this study.

\section{References}

1. Akanji , M.A. (1986). A comparative biochemical study of the interaction of some trypanocides with rat tissue cellular system. Ph. D. Thesis. University of Ife, Ile-Ife Nigeria.

2. Akanji, M. A., Adegoke, O.A. and Oloyede, O.B. (1993). Effect of chronic comsumption of Metabisulphate on the integrity of rat cellular system. Toxicol. 81:173-179. 
3. Akanji, M. A. and Yakubu, M. T. (2000). $\alpha$-Tocopherol protects against metabiosulphate-induced tissue damage in rats. Nig. J. Biochem.Mol. Biol. 15(2):179-183.

4. Aliyu, S., Okoye, Z.S.C and Thomas, S. W. (1995). The hepatoprotective cytochrome $\mathrm{P}_{450}$ enzyme inhibitor isolated from Nigerian medicinal plant: C. planchonii is a zinc salt. J. Ethnopharmacol 48: 89-97.

5. Anaga, A. O. and Oparah, N. Q. (2009). Investigation of the methanol root extract of Cochlospermum planchonii in vitro and in vivo. Pharm. Biol. 47(11): 1027-1034.

6. Anthony, J. P., Fyfe, L. and Smith, H. (2005). Plant active components, a resource for antinparasitic agents.Trend Parasitol. 21:462468.

7. Atawodi, S. E. (2005). Comparative in vitro trypanocidal activities of petroleum, methanol, and aqueous extracts of some Nigerian Savannah plants. Afr. J. Biotechnol. 4:177-182.

8. Benoit-Vical, F., Valentin, A., Mallie, M., Bastide, S. M. and Bessiere, J. M. (1999). In vitro antimalarial activity and cytotoxicity of C. tintorium and C. planchonii leaf extracts and essential oils. Planta Med. 65: 378-381.

9. Blass, K. G., Thiebert, R. J. and Lam, L. K. (1974). Study of mechanism of JAFE reactions. Clin. Chem. 12(7): 336-343.

10. Blench, R. M. (2007). Hausa names for Plants and Trees. 2nd ed. pp. 8.

11. Collins, A. J and Lewis, D. A. (1971). Lysosomal enzyme level in blood of arthritic rats. Biochem. Pharmacol., 28:251-253.

12. European Treaty Series (2005). European Convention for the protection of vertebrate animals used for experimental and other scientific purposes. European Treaty Series, Strasbourg, ETS-123.

13. Evelyn, K. A. and Malloy, H. T. (1938). Micro determination of oxyhaemoglobin, methaemoglobin and sulphaemoglobin in a single sample of blood. J. Biol. Chem., 126: 655

14. Farnsworth N R, Akerele O, Bingel A S, Soejarto D D, Guo Z. (1985). Medical plants in therapy. Bull Wld Hlth Org. 63: 965-981.

15. Grant, G. H. and Kacchman, J. F. (1987). In: "Fundamental of Clinical Chemistry" (Tietz, N.W), 3rd edition. W.B. Sauders Company, Philadelphia. pp.298-320.

16. Igoli, T., Anyim, T. A., Usman, A. A. Oluma, H. O. A. and Igoli, N. P. (2002). Folk medicines of the lower Benue valley of Nigeria, in: Sigh, VK, Govil, JN, Hasmi, S.and Singh, G (Eds), Recent Progress in Medicinal Plants, Vol. 7, Ethnomedicine and Pharmacognosy II. Science Technology Publication, Chicago, Illinois, pp. 327-388.

17. Kincheloe, L. (1997). Herbal medicines can reduce costs in HMO, Herbalgram. 41(49).

18. Mahajan, B. K., (1997). Significance of differences in means. In: Methods in Biostatistics for Medical and Research Workers, 6th ed. New Delhi JAYPEE Brothers Medical Publishers. pp. 130-155.

19. Malomo, S. O. (2000). Toxicological Implication of Ceftriaxone Administration in Rats. Nig. J. Biochem. \& Mol. Biol. 15(1): 33-38.

20. Moudgil K. D. and Narang, B. S. (1989). The liver and the biliary system. In: Talwar GP, Srivastava LM, Moudgil KD (eds.) Textbook of biochemistry and human biology. 2nd ed. New Delhi: Prentice-Hall of India Pvt Ltd, p.271-273.

21. Nakanishi, M. and Goto, K. (1975). Inhibitory effect of anti-inflammatory drugs on enzyme release from rabbit polymorphonucleus leukocytes lysosomes. Biochem. Pharmacol., 24: 421-424.

22. Nduagu, C., Ekefam, E. J. and Nwankiti, A. O. (2008). Effect of crude plant extracts on growth of Colletotrichum capsici (Synd) Butler \& Bisby, causal agent of pepper anthracnose. J. Appl. Sci. 6(2): 184-190.

23. Palambo (2006). Phytochemicals from traditional medicinal plants used in the treatment of diarrhoea: Mode of action and effect on intestinal function. Phytother Res 20: 717-724.

24. Pendota, S.C., Yakubu, M. T., Grieson, D. S., and Afolayan, A. J. (2010). Effect of administration of aqueous extract of Hippobramus pauciflorus leaves in male Wistar rats. Afr. J Tradit. Complement Altern Med. 7(1): 40-46.

25. Ramalingam, V. and Vimaladevi, V. (2002). Effect of mercuric chloride on membrane-bound enzymes in rat testis. Asian J. Androl., 4: 309-311.

26. Saad, B., Azaizeh, H., Abu-Hijleh, G and Said, S. (2006). Safety of traditional Arab herbal medicine. Evidence-Based Compl. \& Altern. Med., 3: 433-439.

27. Shahjahan, M., Sabitha, K. E., Malbika, J. and Shyamala-Devis, C. S. (2004). Effect of Solanum trilobatum against carbon tetrachloride induced hepatic damage in albino rats. Indian. J. Med. Res. 120: 194-198.

28. Togola, A., Austerheim, I., Theis, A., Diallo, D., and Paulsen, B. S. (2008). Ethnopharmacological uses of E. Senegalensis : A comparism of three areas in Mali and a link between traditional knowledge and Biological Ethnobiology. Ethnomed 4(6): 1-10.

29. Umezawa, H. and Hooper, I. R. (1982). Amino-glycoside antibiotic. Springer- Verlag. Berlin, Hadelberg. N.Y.

30. Veniamin, M. P. and Varkirtzi, C. (1970). Chemical basis of the carbamidodi-acetyl micro-method for estimation of ure, citrulline and carbamyl derivatives. Clin. Chem., 16: 3-6.

31. Woodman, D. D. (1996). Assessment of hepatoxicity. In: Evans, G. O. (ed.). Animal Clinical Chemistry, A Primer for Toxicologist. Taylor \& Francis, London, pp. 71-86.

32. Wright, P. J., and Plummer, D. T.(1974). The use of urinary enzyme measurement to detect renal damages caused by nephrotic compounds. Biochem. Pharmacol., 12: 65.

33. Wright, P. J., Leathwood, P.D. and Plummer, D. T. (1972a). Enzyme in rat urine: Alkaline phosphtase, Enzymologia, 42: 317-327.

34. Wright, P. J., Leathwood, P.D., and Plummer, D. T. (1972b). Enzyme in rat urine: Acid phosphtase, Enzymologia, 42: 459-462.

35. Yakubu, M. T. (2006). Aphrodisiac and toxicological evaluation of aqueous extract of Fadogia agrestis (Schweinf. Ex Heirn) stem in male rats. Ph.D Thesis, University of Ilorin, Ilorin, Nigeria.

36. Yakubu, M. T., Bilbis, L. S., Lawal, M., and Akanji., M. A. (2003). Effect of Repeated Administration of sildenafl citrate on selected enzyme activities of liver and kidney of male albino rats. Nig. J. Pure \& Appl. Sci., 18: 1395-400.

37. Yakubu, M. T., Bukoye, B. B., Oladiji, A. T. and Akanji, M. A. (2009). Toxicological implications of aqueous extract of Bambusa vulgaris leaves in pregnant Dutch rabbits. Human \& Exp. Toxicol. 28(9): 591-598. 